\title{
Effect of Administration of Mercuric Chloride on the Social Behavior, Neuromuscular Coordination, Motor Activity, Blood Parameters and Liver Structure Alterations in Mice Offspring
}

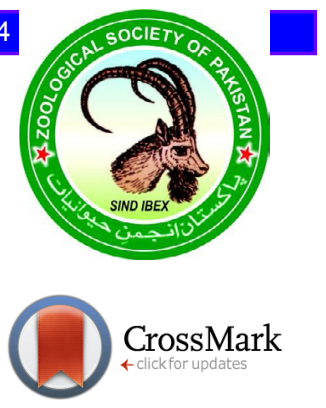

\author{
Gasem Mohammad Abu-Taweel \\ Department of Biology, College of Sciences, Jazan University, P.O. Box 2079, Jazan \\ 45142, Saudi Arabia
}

\begin{abstract}
A B S T R A C T
The present study was carried out to investigate the exposure of mercuric chloride on mice offsprings' social behavior, neuromuscular coordination, motor activity, blood parameters and liver structure alterations. On the first day of pregnancy, 30 pregnant mice were equally divided into three groups. Tap water was provided to the control group (Group I). Group II and Group III animals were orally received 5 and $10 \mathrm{ppm}$ of $\mathrm{HgCl}_{2}$. The treatment started the first day of pregnancy and continued to the day 15 after birth thearafter the dams were sitched to tap water. The behavioral results showed a significant increase in nonsocial investigation while social investigation and defense activities were decreased significantly. Results indicated that both latencies, to first threat and first attack were increased significantly, while the duration time of flight, number of fights, nasonasal, nasogenital and rears were decreased significantly. The latency to first bite was significantly increased, however the number of bites was decreased dramatically when compared with control. Motor activity and grip strength data were decreased significantly in exposed offsping. Interestingly, blood parameters like packed cell volume, red blood cell count, hemoglobin content, platelets and white blood cells were significantly reduced, while the glucose level and gamma glutamyl transferase (GGT) activity were elevated in treated animals. Liver was damaged and the liver sections showed vacuolization of the cytoplasm of the hepatocytes, necrosis of hepatocytes, polymorphism of tissue, nuclei and vessel congestions when compared with control group. The development, behavioral, biochemical and histological disorders were observed due to exposure to mercury via placenta during pregnancy and / or during lactation through weaning period. Overall, mercury chloride administration had direct influence on the social behavioural and blood parameters in the mice offsprings.
\end{abstract}

\begin{tabular}{l} 
Article Information \\
\hline Received 11 July 2018 \\
Revised 24 May 2019 \\
Accepted 26 September 2019 \\
Available online 28 February 2020 \\
Key words \\
\hline $\begin{array}{l}\text { Mercuric chloride, Mice offspring, } \\
\text { Social behavior, Motor activity, Blood } \\
\text { parameters, Liver }\end{array}$ \\
\hline
\end{tabular}

\section{INTRODUCTION}

$\mathrm{M}$ ercury $(\mathrm{Hg})$ is a heavy metal that has high toxicity propeties. Hg exists in three forms: elemental $\mathrm{Hg}$, inorganic $\mathrm{Hg}$ compounds (primarily mercuric chloride, $\mathrm{HgCL}_{2}$ ), and organic $\mathrm{Hg}$ compounds (primarily methyl $\mathrm{Hg}$ ) (Dash and Das, 2012). All forms are used in thermometers, batteries, dental amalgams and skin-lightening creams. $\mathrm{HgCL}_{2}$ is used as a disinfectant and pesticide and is the third most dangerous heavy metal (Zhang et al., 2011; Celikoglu et al., 2015). Methyl Hg is formed from inorganic $\mathrm{Hg}$ ion from methylation process and the exposure to inorganic $\mathrm{Hg}$ is due to working activities like spillage of mercuric compounds on clothes (Bluhm et al., 1992)

\footnotetext{
* Corresponding author: gmabutaweel@jazanu.edu.sa; abutaweelbiochem@gmail.com 0030-9923/2020/0003-0957 \$ 9.00/0

Copyright 2020 Zoological Society of Pakistan
}

or handling of $\mathrm{Hg}$ salts in the laboratories and industries (Augusti et al., 2007). Hg has been widely used in tooth fillings (Fung and Molvar, 1992; Al-Saleh et al., 2012). The safety of $\mathrm{Hg}$-containing dental amalgam to the individual and their health conditions were due to the exposure in various aspects (Martin and Woods, 2006; Arokiyaraj et al., 2015), however, amalgam remains very popular because of its durability, relative cheapness and ease to use (Newman, 1991). It is also widely used to restore posterior teeth in pediatric dentistry (Fuks, 2002; Al-Saleh et al., 2012). In general, $\mathrm{Hg}$ enters the human body and animals through food chains. Fishes were an important source of $\mathrm{Hg}$ in the human body (Maqbool et al., 2016). Gao et al. (2018) reported that the poisoning of children in some Chinese provinces were recorded because of the consumption of fish contaminated with $\mathrm{Hg}$.

It was previously reported that almost all forms of $\mathrm{Hg}$ are toxic to the organisms (Clarkson and Magos, 2006; Chehimi et al., 2012). Toxicity of $\mathrm{Hg}$ was mainly associated 
with sulfhydryl groups (-SH), forming higly stable complexes and causing structural changes of sulfhydryl group in the active site of enzymes and the inactivation of their active sites (Rooney, 2007). In all tissues, exposure to $\mathrm{HgCL}_{2}$ elevated lipid peroxidation (Al-Zubaidi and Rabee, 2015). The absorbed $\mathrm{Hg}$ distributed widely to all tissues and caused changes in liver, brain, and other organs (Yoshida et al., 2005; Wadaan, 2009; Chehimi et al., 2012). Exposure to $\mathrm{Hg}$ increased the levels of aspartate aminotransferase (AST), alkaline phosphatase (ALP), urea, alanine aminotransferase (ALT) and creatinine in mice than in control group. The other parameters such as, glutathione (GSH), cholesterol, total protein, hemoglobin $(\mathrm{Hb})$, white blood cells (WBC) and red blood cells (RBC) were significantly decreased in the experimental group. Histopathlogical studies revealed that $\mathrm{HgCL}_{2}$ significantly induced many modifications in kidney and liver in mice (Al-Zubaidi and Rabee, 2015).

Exposure of brain to $\mathrm{Hg}$ caused many diseases, including behavioral dysfunction (Chehimi et al., 2012). Zhang et al. (2013) reported that administration of $\mathrm{HgCL}_{2}$ to mice during pregnancy and lactation influenced the social behavior of offspring. $\mathrm{Hg}$ exposure also led to elevated cytokine levels in offsprings' brains (Yoshida et al., 2005). The present study was aimed to investigate the maternal exposure to $\mathrm{HgCL}_{2}$ during gestation and lactation period on social behavior, neuromuscular coordination, locomotor activity and histological changes in liver of mice offspring.

\section{MATERIALS AND METHODS}

\section{Experimental animals}

About 10-12 week old Swiss-Webster strain mice (males and females) were maintained separately in an opaque cages $(30 \times 12 \times 11 \mathrm{~cm})$ at Animal Facility, Department of Zoology, King Saud University, Riyadh, Saudi Arabia. All animals were maintained under reverse lighting conditions and at an ambient temperature (20 \pm 2 ${ }^{\circ} \mathrm{C}$ ). On the first day of pregnancy of mice, the males were separated from the cages and the females were subjected to various experiments. All experimental protocols were made in accordance with the ethical guidelines for the use and care of laboratory animals. The experimental protocols were approved by the local Ethics and Care of Experimental Animals Committee.

\section{Hg exposure and experimental design}

Thirty pregnant mice were selected based on the appearance of Vaginal plug and were equally divided into three groups. Only tap water was given to Group I and considered as control. Groups $\Pi$ animals received 5 ppm
$\mathrm{HgCl}_{2}$ orally, whereas, $10 \mathrm{ppm}$ of $\mathrm{HgCl}_{2}$ was administered orally to Group III animals. Water and food were provided to all groups except at the time of behavioral trials. The following observations were made on experimental and control groups.

1. Group I was subjected to "standard opponent" test in males and the "tube restraint test" in females.

2. Group II was subjected to motor activity using activity meter and neuromuscular coordination using a grip strength meter.

3. Group $\amalg$ was subjected to liver histological analysis and analysis of various parameters in the blood.

Experiment was started from the first day of pregnancy and it was continued until post-natal day 15 (PD 15). Futher the mothers were switched to tap water. The pups of each experimental group were selected to only eight per dam on the post-natal day1 (PD 1) and were left with their mothers until post-natal day 22 (PD 22). During this time (weaning period), three pups in each litter were marked using various color to differentiate and were subjected to many behavioral experiments under dim lighting (ca 8 lux). All observations were registered on PD 21 and 36 of pup age.

\section{Behavioral studies}

Social behavior of control and experimental mice was carried out using "standard opponent" analysis and the "tube restraint test" was carried out in female experimental mice.

\section{Standard opponent test}

Ten male animals were selected from each set of control and experimental group and maintained individually in new cages for two weeks. After that, all male mice were subjected to "standard opponent" analysis under dim red lighting (ca. 8 lux). The docile and age-matched male individuals (standard opponents) were rendered anosmic by applying $25 \mu \mathrm{l}$ of $4 \%$ zinc sulfate solution to the nasal tract under anesthesia for three days prior to encounters. Then anosmic "standard opponent" intruders were gently introduced in the cages of 'test animals' and the "standard opponent" test of each 'test animal' was analyzed visually for 500s.

The opponents were used to assess the selected "elements" of behavior as described previously (Brain et al., 1987; Abu-Taweel and Ajarem, 2008).

\section{Tube restraint test}

Thirty females were selected to study the 'tube 
restraint test'. Ten females from each treated experimental group were selected for this analysis. The apparatus was designed as described previously (Ajarem and Ahmad, 1992; Abu-Taweel et al., 2006). Briefly, the apparatus consisted of a cylindrical transparent perspex tube with 13 $\mathrm{cm}$ in length and the internal diameter was $3.1 \mathrm{~cm}$. One end of the cylindrical tube was blocked using a perforated perspex wall through which a metal target $(2 \mathrm{~cm}$ length) was attached to a telegraph key/electronic counter arrangement. The experiment was carried out visually as suggested previously (Ajarem and Ahmad, 1994; AbuTaweel et al., 2006) for $500 \mathrm{~s}$ under standard laboratory condition.

\section{Neuromuscular coordination in grip strength meter}

Neuromuscular coordination was evaluated using automated electronic grip strength meter (Biocompare, U.S.A). This device consists of two parts; the first square base is composed of Perspex material and is ending with rectangular column (15 cm ling), on the column cylinder fitted by another column with brass pieces ( $5 \mathrm{~cm}$ long). This is manily used to catch mouse during experiments. Maintenance of mouse was gently started in the tail and was placed in front of a copper piece. Mouse remained in the front by raising the hind limbs of the animal when measuring the power base forelimbs. Then the animal was laid at the rear base to evaluate the tensile strength of the parties Quartet. Then grip strength was calculated by $\mathrm{kg} / \mathrm{m}$ after two min (Ali et al., 2004).

\section{Motor activity test}

Spontaneous motor activity was extensively used in rodents to evaluate the toxicological and pharmacological effects of $\mathrm{Hg}$. Motor activity was elucidated using fully automated electronic activity meter as suggested by Kim et al. (2015) (Ugo Basile, Comerio-Varese, Italy). The vertical and horizontal motor activities were calculated by arrays of infrared beams placed above the floor of the testing place. Interruption of th beams on the " $\mathrm{X}$ " or " $\mathrm{Y}$ " axis generated an electric impulse which was recorded on a digital counter. Each animal was tested individually and the motor activity was registered for $2 \mathrm{~min}$ in the activity meter (Abu-Taweel et al., 2013a).

\section{Analysis of blood parameters}

Blood was collected aseptically from the retro-orbital plexus of the mice in heparinized vials at the end of the tests. Blood parameters such as, packed cell volume, red blood count, total white blood count, blood platelets count and hemoglobin content were measured using a automated hematology analyzer (T 450,USA).
Random glucose level and GGT activity

The random glucose level and GGT activity were estimated in the blood using an automatic analyzer (Hitachi automatic analyzer-902, Roche Diagnostic,USA to estimate random glucose level and (Reflotron Plus System, Roche, Germany) to estimate GGT.

\section{Histological tests}

For the histological slide preparation, liver was collected from sacrificed animals fixed in Bouin's fixative. Sections $(4-5 \mu \mathrm{m})$ were prepared with a microtome, dewaxed, hydrated and stained in Mayer's haemalum solution for $3 \mathrm{~min}$. The sections were stained with hematoxylin and Eosin for one min, washed in tap water and dehydrated in ethanol as described by (Ebaid et al., 2012).

\section{Statistical analysis}

The experimental data of tube restraint tests and standard opponent were analyzed within the experimental groups by using analysis of variance (ANOVA) and subsequently analyzed using Mann-Whitney $U$ tests. Locomotry behavior data, blood parameters, neuromuscular activities in grip strength meter and biochemical analysis were compared within the experimental animals by using analysis of variance (ANOVA) by Minitab computer program. Further analysis was made using Student ${ }^{\mathrm{e}} \mathrm{s}$ t-test. The significance levels were defined at $\mathrm{P} \leq 0.05, \mathrm{P} \leq 0.01$, and $\mathrm{P} \leq 0.001$ (Yamane, 1973).

\section{RESULTS}

\section{Social behavior in standard opponent test}

Table I displayed the prenatal exposure of $\mathrm{Hg}$ induced social behavior deficits. Non-social investigation and threat were increased $(P<0.001, P<0.05)$ respectively, while social investigation and defense were decreased at $P<0.01$ and $P<0.05$ level respectively when compared with control. Both latencies, to first threat and first attack were increased significantly $(P<0.001)$ while the amount of fight $(P<0.01)$, nasonasal, nasogenital $(\mathrm{P}<0.05)$ and rears were decreased significantly $(P<0.05, P<0.01)$ when compared with control mice (Table I). Table II shows that exposure to $\mathrm{HgCL}_{2}$ induced defense behavior in female offspring. The latency to first bite was increased $(\mathrm{P}<0.05)$, while the number of bites was decreased $(\mathrm{P}<0.01, \mathrm{P}<0.001)$ when compared with control group.

\section{Neuromuscular coordination analysis}

Exposure to $\mathrm{Hg}$ influenced on neuromuscular coordination in experimental mice. $\mathrm{Hg}$ exposure reduced neuromuscular coordination significantly in treated animals in both doses $(\mathrm{p}<0.05$ and $\mathrm{p}<0.01)$, respectively, when compared with control animals (Fig. 1). Results 
indicated that the neuromuscular coordination was reduced with respect to the increase in the concentration of the administration of the medrcuric chloride. At $5 \mathrm{ppm}$ concentration the grip strength was $750 \mathrm{~kg} / \mathrm{M}$ and at 10 ppm it was $490 \mathrm{~kg} / \mathrm{M}$ respectively. These results clearly evidenced that the activity was inversely proportional to the concentration of the $\mathrm{HgCL}_{2}$.

Table I. Effects of $\mathrm{Hg}$ perinatal exposure on social behavior acts and postures in male mice offspring. The time allocated to behavior is in seconds (with ranges).

\begin{tabular}{llll}
\hline Group & Control & $\mathbf{5}$ ppm & $\mathbf{1 0} \mathbf{~ p p m}$ \\
\hline Nonsocial & 145.20 & $302.40 * * *$ & $327.90 * * *$ \\
investigation & $(120.30-170.1)$ & $(286.3-315.5)$ & $(295.7-360.2)$ \\
Social & 223.30 & $99.70 * *$ & $94.00 * *$ \\
investigation & $(214.10-232.5)$ & $(98.00-101.4)$ & $(88.00-100)$ \\
Defense & 20.40 & 15.60 & $1.55 *$ \\
& $(20.10-20.70)$ & $(10.80-20.40)$ & $(00.00-3.10)$ \\
Threat & 21.70 & 25.20 & $52.30 *$ \\
& $(20.10-23.30)$ & $(18.00-32.40$ & $(26.60-78.00)$ \\
Attack & 60.30 & $23.25 * * *$ & $8.50 * * *$ \\
& $(40.40-80.20)$ & $(20.00-26.50)$ & $(0.00-17.00)$ \\
Displacement & 29.30 & 33.85 & $13.20 *$ \\
& $(26.50-32.10)$ & $(18.60-49.10)$ & $(4.40-22.00)$ \\
Latency to & 7.50 & $105.00 * * *$ & $309.50 * * *$ \\
threat & $(5.00-10.00)$ & $(90.00-120.00)$ & $(220.00-399)$ \\
Latency to & 40.00 & $170.00 * * *$ & $405.50 * * *$ \\
attack & $(20.00-60.00)$ & $(120-220.00)$ & $(390.00-421)$ \\
No of fights & 19.00 & $4.00 * *$ & $1.50 * *$ \\
& $(18.00-20.00)$ & $(2.00-6.00)$ & $(1.00-2.00)$ \\
No. of naso- & 26.00 & 19.00 & $10.50 *$ \\
nasal contacts & $(25.00-27.00)$ & $(17.00-21.00)$ & $(8.00-13.00)$ \\
No. of naso- & 18.00 & 7.50 & $2.50 *$ \\
genital contacts & $(14.00-22.00)$ & $(5.00-10.00)$ & $(2.00-3.00)$ \\
Wall rears & 13.00 & 11.50 & 7.00 \\
& $(10.00-16.00)$ & $(9.00-14.00)$ & $(6.00-8.00)$ \\
Rears & 16.00 & $5.50 *$ & $3.00 * *$ \\
& $(11.00-1.00)$ & $(14.00-25.00)$ & $(2.00-4.00)$ \\
\hline & & & \\
& & &
\end{tabular}

$*, * *$ and $* * *$ significantly different $(\mathrm{p}<0.05, \mathrm{p}<0.01$ and $\mathrm{p}<0.001)$ respectively from the control by using Mann-Whitney $U$ test and ANOVA.

\section{Motor activity}

$\mathrm{HgCL}_{2}$ induced motor activity in experimental mice (Fig. 2). Vertical and horizontal activities were significantly reduced at $\mathrm{p}<0.001$ level in both doses compared to control group. Results proved that the vertical activity was higly reduced when compared to the horizontal activity. Especially, the vertical activity of control, $5 \mathrm{ppm}$ and $10 \mathrm{ppm}$ concentrations were noted as less than $10 \mathrm{~cm}$ respectively, whereas the horizontal activity was recorded above $100 \mathrm{~cm}$ for both 5 and $10 \mathrm{ppm}$ concentration of the $\mathrm{HgCL}_{2}$ supplementation.

Table II. Effects of $\mathrm{Hg}$ perinatal exposure on defense behavior in female mice offspring.

\begin{tabular}{lll}
\hline Group & \multicolumn{2}{c}{ Measures (Median values with ranges) } \\
\hline & Number of bites & Latency to first bite (sec) \\
\hline Control & 70.0 & 15.0 \\
& $(45.0-96.0)$ & $(10.0-40.0)$ \\
$5 \mathrm{ppm}$ & $36.0 * *$ & 77.0 \\
& $(0.00-41.0)$ & $(0.00-100.0)$ \\
$10 \mathrm{ppm}$ & $10.0 * * *$ & $132.0 *$ \\
& $(0.0-35.0)$ & $(0.0-180.0)$ \\
\hline
\end{tabular}

$*$, ** and $* * *$ significantly different $(\mathrm{p}<0.05, \mathrm{p}<0.01$ and $\mathrm{p}<0.001)$ compared with control group by ANOVA and Mann-Whitney U test.

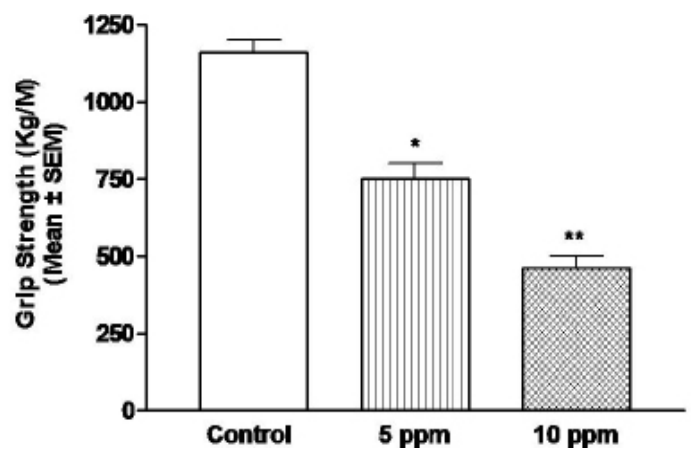

Fig. 1. Effect of perinatal exposure to $\mathrm{Hg}$ on neuromuscular coordination in mice offspring.* and ** showed significant variation at $\mathrm{P}<0.05$ and $\mathrm{P}<0.01$ level respectively compared with control group by ANOVA and student's t-test.

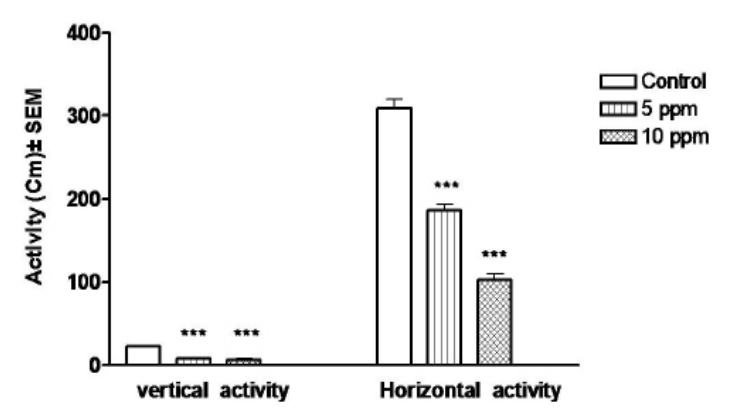

Fig. 2. Perinatal $\mathrm{Hg}$ exposure effects on locomotor activity behavior of mice offspring. ${ }^{* *}$ shows statistically significant variation at $\mathrm{P}<0.001$ level than control group by ANOVA and student's t-test. 

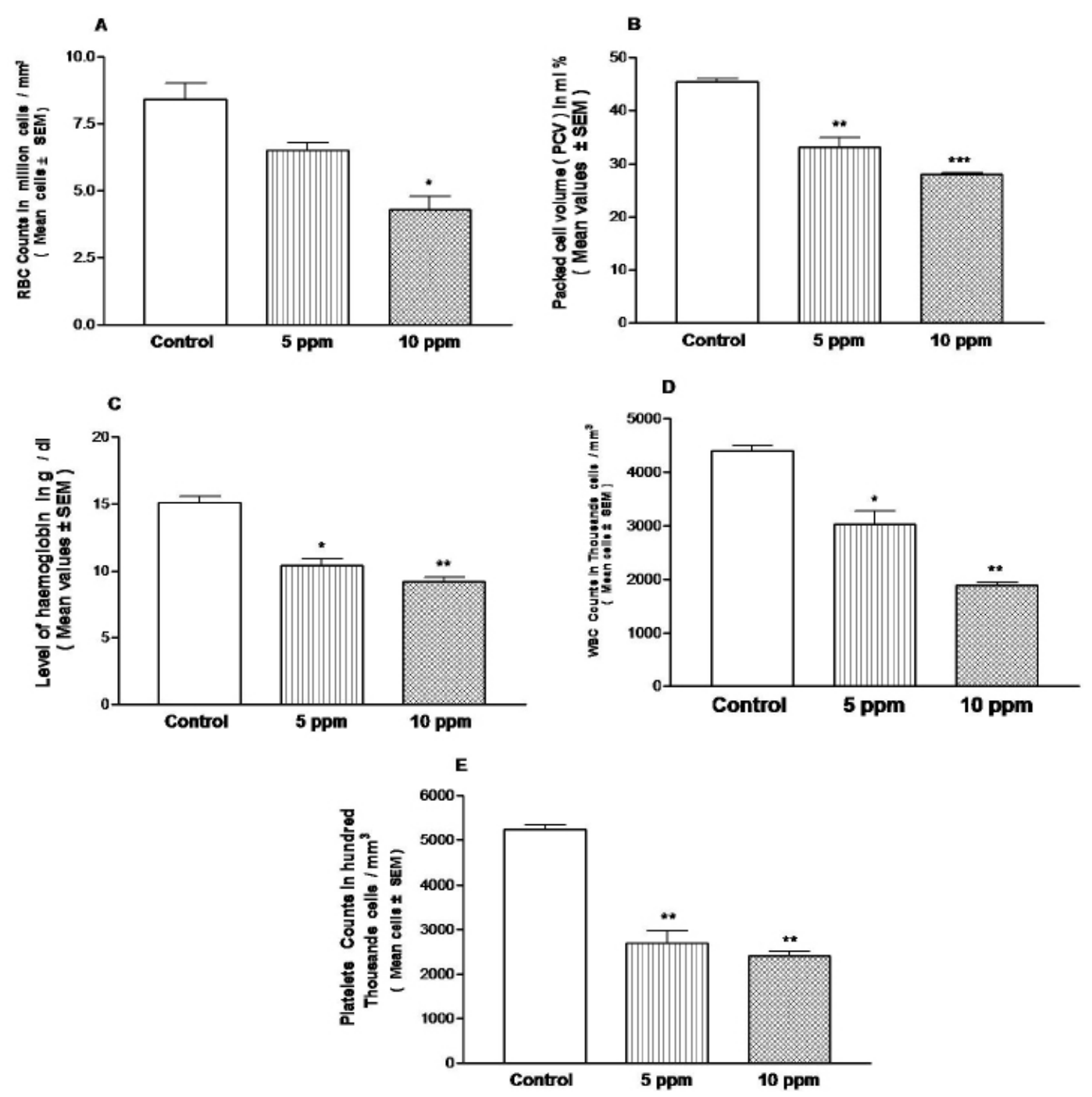

Fig. 3. Effect of Hg toxicity on red blood cells (A), volume of packed red cells (B), hemoglobin content of mice (C), white blood cells (D), platelets (E) of mice offspring. *, ** and *** implied significant different at $\mathrm{p}<0.05, \mathrm{p}<0.01$ and $\mathrm{p}<0.001$ level respectively from the control group by ANOVA.

\section{Analysis of blood parameters}

$\mathrm{HgCL}_{2}$ exposure significantly depleted red blood cell count, white blood cell count, the packed cell volume, hemoglobin content and platelets count (Fig. 3). At 5 and $10 \mathrm{ppm}$ concentration the values of RBC countes were less than 7.5 million cells $/ \mathrm{mm}^{3}$ and 5 million cells/ $\mathrm{mm}^{3}$ respectively, whereas the control experiment noted above 7.5 million cells $/ \mathrm{mm}^{3}$ clearly indicating the direct effect of $\mathrm{HgCL}_{2}$ on the RBC counts. Interestingly, the supplementation of $\mathrm{HgCL}_{2}$ was inversely proportional to the concentration of the packed cell volume. Therefore, it is concluded that the supplementation of the mercurric chloride has direct influence on the alterations of the blood parameters. Similarly, the RBC counts and platelets counts were inversely proportional to the concentrations of $\mathrm{HgCL}_{2}$.

\section{Random glucose level and GGT activity}

Figure 4 showed a significant increase in random glucose level $((p<0.05, p<0.01)$ respectively in the doses of $\mathrm{Hg}$ and $(\mathrm{p}<0.001)$ in GGT activity due to $\mathrm{Hg}$ exposure as compared to control. The level of total glucose concentrations and the gamma glutamyl transferase ranges were directly proportional to the concentrations of the administration of the $\mathrm{HgCL}_{2}$. Compared to the control, the level of the total glucose and the enzyme levels were significantly increased with increase (5 ppm and $10 \mathrm{ppm}$ ) in the concentrations of the $\mathrm{HgCL}_{2}$. 


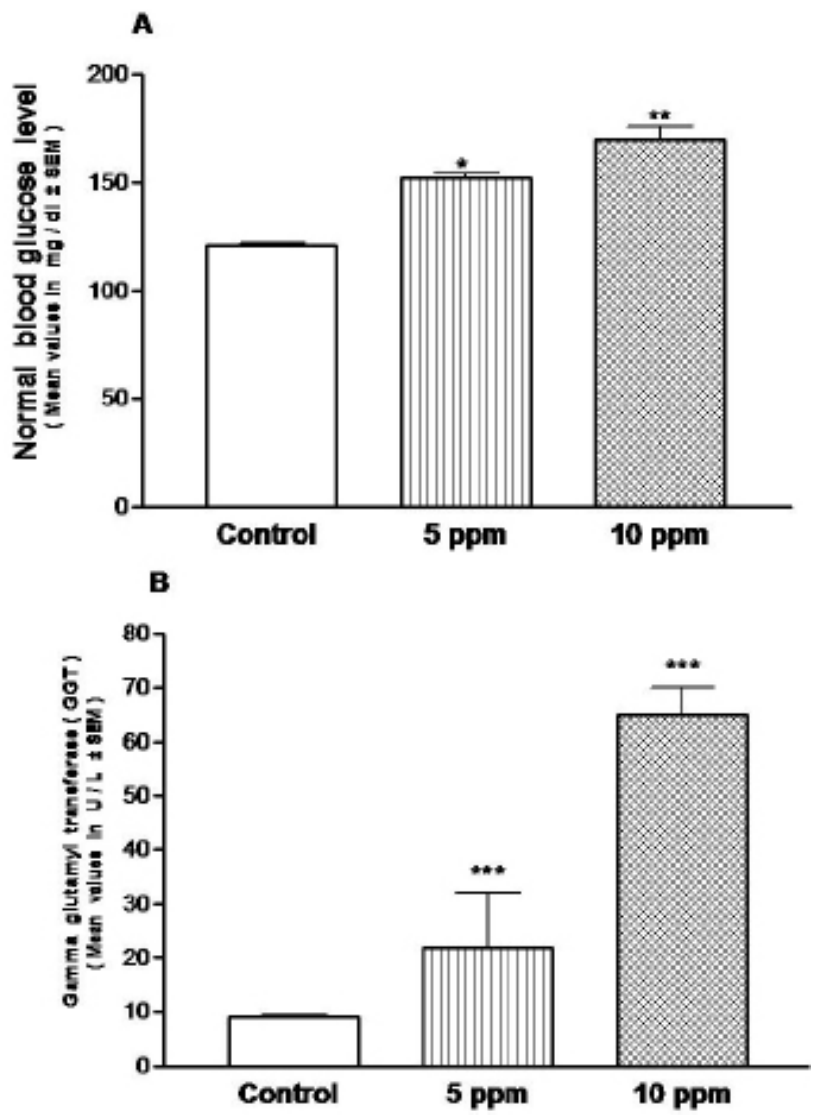

Fig. 4. Effect of $\mathrm{Hg}$ on random glucose level (A), gamma glutamyl transferase (B). *, ** and $* * *$ significantly different at $(\mathrm{p}<0.05, \mathrm{p}<0.01$ and $\mathrm{p}<0.001)$ respectively from the control group by ANOVA student's t-test.

\section{Liver histology}

Figure 5 shows a section from normal and Hg-Treated livers. $\mathrm{B}$ and $\mathrm{C}$ sections of Hg-Treated livers showed a major damage in liver. The liver sections revealed necrosis of hepatocytes, polymorphism of nuclei, tissues, vacuolization of the cytoplasm of the hepatocytes and vessel congestions.

\section{DISCUSSION}

$\mathrm{Hg}$ is a heavy metal that has high toxicity. It exists in three forms: elemental $\mathrm{Hg}$, inorganic $\mathrm{Hg}$ compounds (primarily $\mathrm{HgCL}_{2}$ ), and organic $\mathrm{Hg}$ compounds (primarily methyl Hg) (Dash and Das, 2012). Natural ones exist through soil or water. It also enters industrially through human activities (Wadaan, 2009). Hg enters the bodies of organisms in different ways and accumulates in the tissues. The target tissue of $\mathrm{Hg}$ accumulation is the brain (Al-Saleh, 2012). Toxicity of $\mathrm{Hg}$ results in behavioral, biochemical, blood parameters and organs structural changes (Clarkson and Magos, 2006; Chehimi et al., 2012).

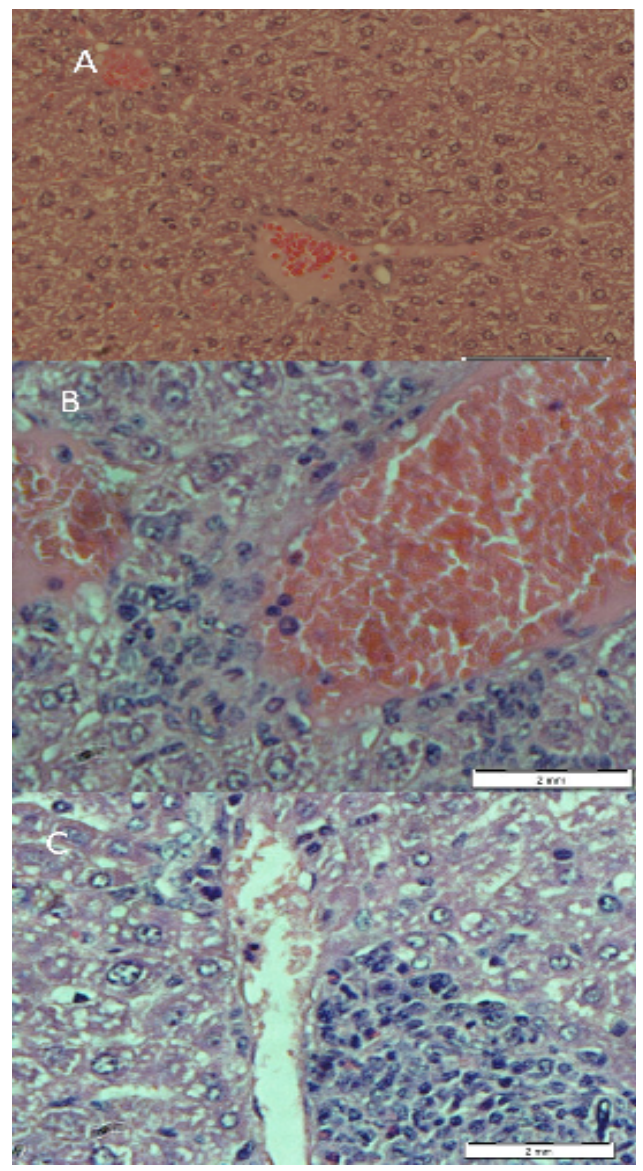

Fig. 5. Effect of $\mathrm{Hg}$ on liver histology $\mathrm{x} 400$. A, Liver plate (control) showed: normal tissue. B, liver (5 ppm) showed: drug induced mild mixed mononuclear inflammatory cells with little esinophiles, congested capillaries and hydropic degenerations.C,liver (10 ppm) showed: drug induced mixed mononuclear inflammatory cells with esinophiles and dilated capillaries and hydropic degenerations.

The present study showed that the peri natal exposure to $\mathrm{HgCL}_{2}$ induced social behavior deficits. Nonsocial investigation and threat were increased while social investigation and defense were decreased as compared to control group. Both latencies, to first threat and first attack were increased significantly while the amount of fight, nasonasal, nasogenital and rears were decreased significantly as compared to control group. The latency to first bite was also increased, while the number of bites was decreased as compared to their control. The results were in agreement with Zhang et al. (2013).

Zhang et al. (2013) attributed social behavior disorders to autoimmunity, which was induced by $\mathrm{Hg}$ 
perinatal exposure. Hei et al. (2011) detected IgG antibrain antibodies in the sera of mice and human with impaired social behaviors and aberrant behaviors were induced in animals after exposure to IgG from mothers (Singer et al., 2009; Zhang et al., 2013). Induction of maternal autoantibody by $\mathrm{Hg}$ was very critical and $\mathrm{IgG}$ can entered fetal brains because blood-brain barrier was less intact or absent in the developing central nervous system (Zhang et al., 2013).

The high amounts of $\mathrm{IgG}$ in the $\mathrm{Hg}$-exposed experimental mice are significantly related to the ability of $\mathrm{Hg}$ to enhance the activation of lymphocyte (Badou et al., 1997). Zitzmann (2006) and Lynn (2008) showed a close relationship between testosterone and different behavioral changes, especially aggression in mice. Animal studies (Abu-Taweel et al., 2013b; Abu-Taweel, 2016) indicated a strong evidence of change, serotonergic neurotransmission, being associated with change in aggression. It was previously reported that the dopaminergic and serotonergic system was modulated by aluminum (Al), cadmium, LPS, MSG and ASP decreased the aggression rate in adult mice (Abu-Taweel et al., 2011; Ebaid et al., 2012; Abu-Tawee et al., 2013a; Abu-Tawee et al., 2014; Abu-Taweel, 2016). Thus, Hg may affect the testosterone level with some other neurotransmitters such as acetylcholine, serotonin and dopamine. Exposure of $\mathrm{Hg}$ in mice critically altered the social behavior by affecting olfactory nerve of the nervous system, which critically control the sense of smell in animals (Park et al., 2000). Inorganic Hg exposure significantly influenced the biochemical parameters in Wistar rat (Merzoug et al., 2009). Exposure of chronic $\mathrm{HgCl}_{2}$ in rats induced functional changes, including motor deficits, long- and short-term memory impairments (Teixeira et al., 2014).

Many studies showed that inorganic $\mathrm{Hg}$ exposure critically caused changes in organ weight, body weight, decrease in renal $\delta$-aminolevulinic acid dehydratase activity, renal histopathological damages and increase in serum creatinine and urea levels (Favero et al., 2014). The effect of $\mathrm{Hg}$ at perinatal exposure on neuromuscular coordination in mice offspring was visible. Experimental animals at both concentrations affected neuromuscular coordination. Vertical and horizontal activities were reduced in the experimental mice significantly. These results were in agreement with earlier findings (Day et al., 2005; Vezer et al., 2005; Yoshida et al., 2005; Zimmermann et al., 2014; Kirkpatrick et al., 2015). Some research groups attributed the low levels of motor activity in $\mathrm{Hg}$-treated animals to the imbalance caused by this element in brain function (Yoshida et al., 2005). The results of this study indicated that weight loss might have affected the structure of the brain and its biological functions, especially the astrocytes were highly important in the process of nerve conduction. The defect may be due to the effect of $\mathrm{Hg}$ on the molecular bond between these cells or channels of communication with gaps between them or to interfere in the structure or function of structural proteins supported by the structure of these cells. Prolonged $\mathrm{Hg}$ exposure weakens or delays the arrival of orders to the muscles, decreases the speed of the nerve impulses, resulting in a very slow response (Cooper and Kusnecov, 2007). The decreases in motor activity in treated animals may be due to muscle weakness due to the imbalance caused by $\mathrm{Hg}$ in the important calcium component in regulating muscle contraction (RamirezBajo et al., 2014; Teixeora et al., 2014). Our results (data not shown) showed anxiety disorders in exposed animals with $\mathrm{Hg}$. The lack of motor activity may be attributed to a lack of energy due to the imbalance caused by $\mathrm{Hg}$ in glucose metabolism. Ramırez-Bajo et al. (2014) reported that exposure to $\mathrm{Hg}$ effected skeletal muscle glycolysis in mice.

$\mathrm{HgCL}_{2}$ exposure led to a significant depletion in some of the observed blood parameters such as red blood cell count, packed cell volume, hemoglobin content, white blood cell count and platelets count.These results are in agreement with previous results (Shaw et al., 1991; AlZubaidi et al., 2015). Some studies attributed a decrease in the number of blood cells to the changes caused by $\mathrm{Hg}$ in the bone marrow of those cells. $\mathrm{Hg}$ accumulated in the bone instead of calcium, causing a malfunction in the bone structure and thus reducing its ability to snythsize blood cells (Rasmussen et al., 2013). Shaw et al. (1991) reported that anemia may arise due to the effect of $\mathrm{Hg}$ in red blood cells. Most of the changes that occur in blood when exposed to $\mathrm{Hg}$ are due to the reduction of the life span of the red blood cells or increase in their degradation. Osinska et al. (2004) pointed out that Al changes the properties and shape of red blood cells, thus changing membrane liquidity. Exposure to $\mathrm{Al}$ increases the production of organic free radicals that oxidize lipids containing unsaturated fatty acids such as malonedialdehyde (MDA), which reacts with amino acids in the membrane of the cells, changes the membrane's liquidity and reduces its ability to restore its original form during passage cells in the capillaries. Some studies proved that the anemia is caused by the ability of Al to produce cells that are different from the normal, such as being small in size or larger than normal, with a lack of natural pigment or increased pigmentation of others (Farina et al., 2002, 2005). Chmielnicka et al. (1996) believes that the cause of anemia is due to imbalance in the biothensysis of the iron element. Some researchers report a decrease in the amount of iron due to the interferometry of $\mathrm{Al}$ in iron biothensysis by inhibiting some important enzymes in its metabolic pathway, such as the alpha-aminolevulinic acid 
dehydratase ( $\delta$-ALA-D) enzyme because the element ion $\left(\mathrm{Al}^{3+}\right)$ is related to the sulfur group in the enzyme (Vieira et al., 2000). The study correlated the depletion of white cells with the high effect of $\mathrm{Al}$ ions on some types of white cells, especially lymphocytes (Gomez et al., 1986). The immunity of people with iron-deficiency disorders is less. White cells lose their ability to function because the blood cells in their various processes need the iron component, which is transported by the transferrin proteins, which are occupied by Al instead of iron (Osinska et al., 2004; Zhang et al., 2019). The effect of $\mathrm{Al}$ on the number of white cells causes changes in its cellular membrane (Shenker et al., 2000). The mechanical effect of $\mathrm{Hg}$ on blood parameters may be similar to that of $\mathrm{Al}$ (Su et al., 2008).

The present study recorded the increase of the random glucose level in treating animals with $\mathrm{Hg}$. Dufault et al. (2015) revealed that glucose levels were higher in human with blood inorganic Hg. Their results indicated that organic $\mathrm{Hg}$ exposure affected insulin levels, but not glucose levels, whereas chronic $\mathrm{Hg}$ exposure affected blood glucose levels. Maqbool et al. (2016) reported that hyperinsulinemia represented high risk of type 2 diabetes mellitus and this could be due the the resistance of insulin. Jeppesen et al. (2015) reported a significant association between diabetes mellitus (DM) risk and total blood $\mathrm{Hg}$ concentrations. Roya et al. (2017) concluded that there was a strong relationship between $\mathrm{Hg}$ exposure and diabetes mellitus. Previous reports showed that organic form of $\mathrm{Hg}$ could be a major cause of insulin resistance and type 2 diabetes mellitus (Chang et al., 2011). DNA methylation also plays a key role in the regulation of genes involved in glucose homeostasis. GLUT4 gene plays a major role in regulating whole body glucose homeostasis. The role of $\mathrm{Hg}$ in affecting LH levels has been studied. LH is among the known regulators of insulin release in pancreatic cells. Reports have linked chronic $\mathrm{Hg}$ exposure with reduced levels of LH (Dufault et al., 2015). Al and Hg are strong oxidizing agents that affect living cells and their functions. It is possible that the mechanisms of their effect on these cells may be similar. Yousef (2004) attributed the increase in sugar in the rabbit blood due to $\mathrm{Al}$ due to the imbalance caused by the element in carbohydrate metabolism to increase the glycogenolysis form the liver as a result of the oversecretion of alpha cells in the islands of Langerhans in glucagon hormone. El-Demerdash (2004) confirmed the conclusion of the previous study, but attributed the increase in sugar to the excessive secretion of adrenocorticotrophic hormone, which stimulated adrenal cortex hormones such as glucocorticoids, especially cortisol, which stimulated glucose production of non-carbohydrate substances.

The results revealed that the increase in GGT activity was due to the $\mathrm{Hg}$ exposure as compared to control. This finding was similar to previous reports (Wadaan, 2009; Lee et al., 2017; Choi et al., 2017). The biological mechanism of associations between $\mathrm{Hg}$ exposure and liver dysfunction is mainly explained by oxidative stress, cell death, and impairment of metabolism (Choi et al., 2017). Some studies have suggested an inverse relationship between GGT enzyme activity and some antioxidants like a-carotene, lycopene and vitamin $\mathrm{C}$. These studies suggested that GGT might be considered an early oxidative stress marker (Lim et al., 2004). Wadaan (2009) observed that $\mathrm{Hg}$ exposure to male rats elevated the levels of liver enzymes such as, GGT, ALT, AST and necrotic changes were found in most of the liver tissues.

The liver sections showed necrosis of hepatocytes, vacuolization of the cytoplasm of the hepatocytes, polymorphism of nuclei and tissue and vessel congestions. These findings were in agreement with previous studies (AlAttar, 2011; Burger et al., 2011; Quirino et al., 2012; Ibegbu et al., 2014). Also, $\mathrm{HgCL}_{2}$ exposure to experimental rats showed congestion of hepatoportal blood vessels, edema in the portal tract, congestion of central vein indicating critical toxic effect of $\mathrm{HgCL}_{2}$ (Ibegbu et al., 2014). Because of exposure to $\mathrm{HgCL}_{2}$, the metabolic pathway of Kupffer cells and liver hepatocytes were affected and implied chronic illness of liver (Kumar et al., 2010; Sujatha et al., 2011).

Liver toxicity is the condition of critical liver damage and at this stage some cells get infiltrated very close to the damaged hepatocytes and critically play an important role in the development of fibrosis (Agarwal et al., 2010; Ibegbu et al., 2013). This fibrosis leads to Liver cirrhosis which is highly irreversible (Junqueira and Caneiro, 2005; Hesse, 2007; Quirino et al., 2012). Liver damage critically decreased the synthesis of proteins and these finding implied degradation of liver cells (Trebucobich et al., 2014). $\mathrm{HgCL}_{2}$ toxicity induced the formation of reactive oxygen species (ROS) and critically promoted damages in liver tissues, where liver cells were damaged due to the toxic effect of $\mathrm{Hg}$ as observed in the present investigation. Hence, an increased level of ROS formation by the exposure to $\mathrm{HgCL}_{2}$ stimulated not only the alternation of functional properties and biochemical changes but also caused liver cell damage (Bharathi et al., 2014).

\section{CONCLUSION}

In summary, the administration of $\mathrm{HgCL}_{2}$ to mice offspring directly affected the social behavior, neuromuscular coordination, motor activity and blood parameters. Results confirmed that the administration of different concentrations of $\mathrm{HgCL}_{2}$ direcly affected the behavioural studies such as social behavior, neuromuscular coordination and vertical and horizontal portion of the 
motor region of spinal cord. The results indicated that the different cocnetrations of the $\mathrm{HgCL}_{2}$ were inversely proportional to the activity of the behavioural aspects. $\mathrm{Hg}$ toxicity induced oxidative stress in the experimental mice and this was mainly due to the formation of toxic $\mathrm{Hg}$ metal in the form highly stable complexes with the sulfhydryl groups of various enzymes and proteins. Interestingly, blood parameters suh as packed cell volume, red blood cell count, hemoglobin content, platelets and white blood cells were significantly reduced, while the glucose level and gamma glutamyl transferase (GGT) activity were elevated in treated animals. The present finding showed the risk of $\mathrm{Hg}$ exposure on neonates, fetuses and the possibility of transport simply through milk and/or placenta. Further studies are required to investigate the effect of behavior changes and medication and/or antioxidant which may reduce the effect of toxic elements.

\section{ACKNOWLEDGEMENTS}

The author is thankful to the Deanship of Scientific Research, College of Education, Research Center at Imam Abdurahman Bin Faisal University for supporting this research. The author is also thankful to Dr. Mohsen Almutary for his technical assistance.

\section{Statement of conflict of interest}

Authors declare no conflict of interest.

\section{REFERENCES}

Abu-Taweel, G., 2016. Effect of monosodium glutamate and aspartame on behavioral and biochemical parameters of male albino mice. Afri. J. Biotechnol., 15: 601-612. https://doi.org/10.5897/ AJB2015.15199

Abu-Taweel, G., Zyadah, M., Ajarem, J. and Ahmad, M., 2014. Cognitive and biochemical effects of monosodium glutamate and aspartame, administered individually and in combination in male albino mice. Neurotoxicol. Teratol. J., 42: 60-67. https:// doi.org/10.1016/j.ntt.2014.02.001

Abu-Taweel, G., Ajarem, J.S. and Ahmad, M., 2013a. Protective effect of curcumin on anxiety, learning behavior, neuromuscular activities, brain neurotransmitters and oxidative stress enzymes in cadmium intoxicated mice. J. Behav. Brain Sci., 3: 74-84. https://doi.org/10.4236/jbbs.2013.31008

Abu-Taweel, G., Ajarem, J.S., Ebaid, H. and Rady, A.M., 2013b. Behavioral changes induced by prenatal acute endotoxemia in mice offspring. Pakistan $\mathrm{J}$. Zool., 45: 359-369.
Abu-Taweel, G.M., Ajarem, J.S. and Ahmad, M., 2012. Neurobehavioral toxic effects of perinatal oral exposure to aluminium on the developmental motor reflexes, learning, memory and brain neurotransmitters of mice offspring. Pharmacol. Biochem. Behav., 101: 49-56. https://doi. org/10.1016/j.pbb.2011.11.003

Abu-Taweel, G.M., Ajarem, J.S. and Ebaid, H. 2011. Aluminum-induced testosterone decrease results in physiological and behavioral changes in male mice. African J. Biotech., 10: 201-208.

Abu-Taweel, G.M. and Ajarem, J.S., 2008. Effect of perinatal lead exposure on the social behaviour of laboratory mice offspring at adolescent age. Saudi J. biol. Sci., 15:67-72.

Abu-Taweel, G., Ajarem, J.S. and, Ahmad, M., 2006. Effect of prenatal lead in the cross-fostered mice offspring. Saudi J. biol. Sci., 13: 80-90.

Agarwal, R., Raisuddin, S., Tewari, S., Goel, S.K., Raizada, R.B. and Behari, J.R., 2010. Evaluation of comparative effect of pre- and post-treatment of selenium on mercury-induced oxidative stress, histological alterations, and metallothionein mRNA expression in rats. J. Biochem. mol. Toxicol., 24: 123-135. https://doi.org/10.1002/jbt.20320

Ajarem, J.S. and Ahmad, M., 1994. Effects of consumption of fresh kolanut extract by female mice on the postnatal development and behaviour of their offspring. J. King Saud Univ. Sci., 6: 41-50.

Ajarem, J.S. and Ahmad, M., 1992. Effects of perinatal exposure of cardamom (Elettaria cardamomum) on the post-natal development and social behaviour of mice ffspring. J. King Saud Univ. Sci., 4: 151-162.

Ali, A., Ahmad. F.J., Pillai, K.K. and Vohora, D., 2004. Evidence of the antiepileptic potential of amiloride with neuropharmacological benefits in rodent models of epilepsy and behavior. Epilepsy Behav., 5: 322328. https://doi.org/10.1016/j.yebeh.2004.01.005

Al-Saleh, I., Al-Sedairi, A. and Elkhatib, R., 2012. Effect of mercury $(\mathrm{Hg})$ dental amalgam fillings on renal and oxidative stress biomarkers in children. Sci. Total Environ., 431: 188-196. https://doi.org/10.1016/j. scitotenv.2012.05.036

Al-Attar, A.M., 2011. Vitamin E attenuates liver injury induced by exposure to lead, mercury, cadmium and copper in albino mice. Saudi J. biol. Sci., 18: 395401. https://doi.org/10.1016/j.sjbs.2011.07.004

Al-Zubaidi, E.S. and Rabee, A.M., 2015. Effect of mercuric chloride on biochemical and hematological parameters in male albino mice. Int. J. Sci. Res., 6: 634-639.

Arokiyaraj, S., Saravanan, M., Badathala, V., 2015. 
Green synthesis of Silver nanoparticles using aqueous extract of Taraxacum officinale and its antimicrobial activity. South Indian J. biol. Sci., 2: 115-118. https://doi.org/10.22205/sijbs/2015/v1/ i2/100433

Augusti, P.R., Conterato, G.M.M., Somacal, S., Einsfeld, L., Ramos, A.T., Hosomi, F.Y.M., Graça, D.L. and Emanuelli, T., 2007. Effect of lycopene on nephrotoxicity induced by mercuric chloride in rats. J. Basic Clin. Pharmacol. Toxicol., 100: 398-402. https://doi.org/10.1111/j.1742-7843.2007.00067.x

Badou, A., Savignac, M., Moreau, M., Leclerc, C., Pasquier, R., Druet, P. and Pelletier, L., 1997. $\mathrm{HgCl}_{2}$-induced interleukin-4 gene expression in $\mathrm{T}$ cells involves a protein kinase $\mathrm{C}$-dependent calcium influx through L-type calcium channels. J. biol. Chem., 272: 32411-32418. https://doi.org/10.1074/ jbc.272.51.32411

Bharathi, E., Jagadeesan, G. and Vijayakumar, M., 2014. Hepato-ameliorative effect of hesperidin and ellagic acid on mercuric chloride intoxicated rats. Biomed. Aging Pathol., 4:17-21. https://doi.org/10.1016/j. biomag.2013.10.002

Bluhm, R.E., Bobbitt, R.G. and Welch, L.W., 1992. Elemental mercury vapor toxicity, treatment and prognosis after acute, intensive exposure in chloralkali plant works. Part I: history, neuropsychological findings and chelator effects. Hum. Exp. Toxicol., 11: 201-210. https://doi. org/10.1177/096032719201100308

Brain, P.F., Ajarem, J.S. and Petkov, V.V., 1987. The utility of ethological assessments of murine agonistic interactions in behavioural teratology: the foetal alcohol syndrome, In: Ethopharmacology of agonistic behaviour in animals and humans (eds. B. Oliver, J. Mos and P.F. Brain). Martinus Nijhoff Publishers Dordrecht, pp. 110-121. https://doi. org/10.1007/978-94-009-3359-0_7

Burger, J., Jeitner, C. and Gochfeld, M., 2011. Locational differences in mercury and selenium levels in 19 species of saltwater fish from New Jersey. J. Toxicol. environ. Hlth., 74: 863-874. https://doi.org/10.1080/ 15287394.2011.570231

Celikoglu, E., Aslanturk, A. and Kalender, Y., 2015. Vitamin $\mathrm{E}$ and sodium selenite against mercuric chloride-induced lung toxicity in the rats. Braz. Arch. Biol. Technol., 58: 587-594. https://doi.org/10.1590/ S1516-8913201500098

Chang, J.W., Chen, H.L., Su, H.J., Liao, P.C., Guo, H.R. and Lee, C.C., 2011. Simultaneous exposure of non-diabetics to high levels of dioxins and mercury increases their risk of insulin resistance. J. Hazard.
Mater., 185: 749-755. https://doi.org/10.1016/j. jhazmat.2010.09.084

Chehimi, L., Roy, V., Jeljeli, M. and Sakly, M., 2012. Chronic exposure to mercuric chloride during gestation affects sensorimotor development and later behaviour in rats. Behav. Brain Res., 234: 43-50. https://doi.org/10.1016/j.bbr.2012.06.005

Chmielnicka, J., Nasiadek, M., Lewandowska-Żyndul, E. and Pińkowski, R.1996. Effect of aluminum on hematopoiesis after intraperitoneal exposure in rats. Ecotoxi. Environ.Safe., 33: 201-206.

Choi, J., Bae, S., Lim, H., Lim, J., Lee, Y., Mina, Ha, M. and Kwon, H., 2017. Mercury exposure in association with decrease of liver function in adults: A longitudinal study. J. Prev. Med. Publ. Hlth., 50: 377-385. https://doi.org/10.3961/jpmph.17.099

Clarkson, T.W. and Magos, L., 2006. The toxicology of mercury and its chemical compounds. Crit. Rev. Toxicol., 36: 609-662. https://doi. org/10.1080/10408440600845619

Cooper, J.F. and Kusnecov, A.W., 2007. Methyl mercuric chloride induces activation of neuronal stress circuitry and alters exploratory behavior in the mouse. Neuroscience, 148: 1048-1064. https://doi. org/10.1016/j.neuroscience.2007.07.034

Dash, H.R. and Das, S., 2012. Bioremediation of mercury and importance of bacterial margins. Int. Biodeterior. Biodegrad., 75: 207-213. https://doi.org/10.1016/j. ibiod.2012.07.023

Day, J.J., Reed, M.N. and Newland, M.C., 2005. Neuromotor deficits and mercury concentrations in rats exposed to methyl mercury and fish oil. Neurotoxicol. Teratol., 27: 629-641. https://doi. org/10.1016/j.ntt.2005.03.011

Dufault, R., Berg, Z., Crider, R., Schnoll, R., Wetsit, L., Wayne, Two Bulls, W.T., Steven, G., Gilbert, S.G., Kingston, H.M., Wolle, M.M., Rahman, G.M.M. and Laks, D.R., 2015. Blood inorganic mercury is directly associated with glucose levels in the human population and may be linked to processed food intake Integr. Mol. Med., 2: 166-179. https://doi. org/10.15761/IMM.1000134

Ebaid, H., Ajarem, J. and Abu Taweel, G., 2012. Acute endotoxemia during gestation induces organ dysfunction and tissue damage in mouse offspring. Pakistan J. Zool., 44: 765-776.

El-Demerdash, F.M., 2004. Antioxidant effect of vitamin $\mathrm{E}$ and selenium on lipid peroxidation, enzyme activities and biochemical parameters in rats exposed to aluminum. J. Trace Elem. Med. Biol., 18: 113121. https://doi.org/10.1016/j.jtemb.2004.04.001

Farina, M., Lara, F.S., Brandao, R., Jacques, R. and 
Rocha, J.B., 2002. Effects of aluminum sulfate on erythropoiesis in rats. Toxicol. Lett., 132: 131-139. https://doi.org/10.1016/S0378-4274(02)00077-2

Farina, M., Rotate, L.N., Soares, F.A.A., Jardim, F., Jacques, R., Souza, D.O. and Rocha, J.B.T., 2005. Hematological changes in rats chronically exposed to oral aluminum. Toxicology, 209: 29-37. https:// doi.org/10.1016/j.tox.2004.12.005

Favero, A.M., Oliveira, C.S., Franciscato, C., Oliveira, V.A., Pereira, J.S.F. and Bertoncheli, C.M., 2014. Lactating and non-lactating rats differ to renal toxicity induced by mercuric chloride: the preventive effect of zinc chloride. Cell Biochem. Funct., 32: 420-428. https://doi.org/10.1002/cbf.3032

Fuks, A.B., 2002. The use of amalgam in pediatric dentistry. Pediatr. Dent., 24: 448-455.

Fung, Y.K. and Molvar, M.P., 1992. Toxicity of mercury from dental environment and from amalgam restorations. Clin. Toxicol., 30: 49-61. https://doi. org/10.3109/15563659208994445

Gao, Z., Li, M., Wang, J., Yan, J., Zhou, C. and Yan, C., 2018. Blood mercury concentration, fish consumption and anthropometry in Chinese children: A national study. Environ. Int., 110: 14-21. https://doi.org/10.1016/j.envint.2017.08.016

Gomez, M., Domingo, J.L., Llobet, J.M., Tomas, J.M. and Corbella, J., 1986. Short-term oral toxicity study of aluminum in rats. Arch. Farmacol. Toxicol., 12: $145-151$.

Hazelhoff, M.H. and Torres, A.M., 2018. Gender differences in mercury-induced hepatotoxicity: Potential mechanisms. Chemosphere, 202: 330-338. https://doi.org/10.1016/j.chemosphere.2018.03.106

Heo, Y., Zhang, Y., Gao, D., Miller, V.M. and Lawrence, D.A., 2011. Aberrant immune responses in a mouse with behavioral disorders. PLoS ONE, 6: e20912. https://doi.org/10.1371/journal.pone.0020912

Hesse, R.W., 2007. Jewelry making through history. Greenwood Publishing Group. P. 120. ISBN 0-31333507-33509.

Ibegbu, A.O., Ayuba, M., Animoku, A.A., Brosu, D., Adamu, S.A., Adamu, P., Hamman, W.O., Umana, U.E. and Musa, S.A., 2014. Effect of ascorbic acid on mercury-induced changes on the liver in adult wistar rats. IOSR J. Dent. Med. Sci., 13:10-16.

Ibegbu, A.O., Alatise, A.T., Babatunde, A.O., Dassah, J.S., Umana, U.E., Hamman, W.O., Musa, S.A. and Akpulu, P.S., 2013. Effects of vitamin E on phostoxininduced changes in the liver and biochemical parameters of adult wistar rats. J. Biol. environ. Sci., 7: 121-129. https://doi.org/10.4103/15962393.127963
Jeppesen, C., Valera, B., Nielsen, N.O., Bjerregaard, P. and Jorgensen, M.E., 2015. Association between whole blood mercury and glucose intolerance among adult Inuit in Greenland. Environ. Res., 143: 192197. https://doi.org/10.1016/j.envres.2015.10.013

Junqueira, L.C. and Caneira, J., 2005. Basic histology-text and atlas. $11^{\text {th }} \mathrm{Ed}$. McGraw-Hills Access Medicine.

Kim, Y.O., Kim, Y., Lee, K., Na, S.W., Hong, S.P., Arasu, M.V., Yoon, Y.W. and Kim, J., 2015. Panax ginseng improves functional recovery after contusive spinal cord injury by regulating the inflammatory response in rats: an in vivo study. Evid. Based Complem. Alternat. Med. 2015: ID 817096, p. 7. https://doi. org/10.1155/2015/817096

Kirkpatrick, M., Benoit, J., Everett, W., Gibson, J., Rist, M. and Fredette, N., 2015. The effects of methylmercury exposure on behavior and biomarkers of oxidative stress in adult mice. NeuroToxicology, 50: 170-178. https://doi.org/10.1016/j.neuro.2015.07.001

Kumar, V.V., Amala, A.P., Sudheer, K.C., Vimal, V. and Veira, B.T.S., 2010. Hypolipidemic effect of Allium cepa, Linn (onion) in lead acetate intoxicated male albino rats. Der Pharm. Sin., 1: 64-68.

Lee, M.R., Lim, Y.H., Lee, B.E. and Lee, Y.C., 2017. Blood mercury concentrations are associated with decline in liver function in an elderly population: a panel study. Environ. Hlth., 16: 17-25. https://doi. org/10.1186/s12940-017-0228-2

Lim, J.S., Yang, J.H., Chun, B.Y., Kam, S., Jacobs, D.R.Jr. and Lee, D.H., 2004. Is serum gammaglutamyltransferase inversely associated with serum antioxidants as a marker of oxidative stress? Free Radic Biol. Med., 37: 1018-1023. https://doi. org/10.1016/j.freeradbiomed.2004.06.032

Lynn, S.E., 2008. Behavioral insensitivity to testosterone: why and how does testosterone alter paternal and aggressive behavior in some avian species but not others? Gen. Comp. Endocrinol., 157: 233-240. https://doi.org/10.1016/j.ygcen.2008.05.009

Maqbool, F., Bahadar, H., Kamal, N.K., Maryam, Baeeri, M., Rahimifard, M., Navaei-Nigjeh, M., Seyedeh, F., Ghasemi-Niri, S.F. and Abdollahi, M., 2016. Effects of methyl mercury on the activity and gene expression of mouse Langerhans islets and glucose metabolism. Fd. Chem. Toxicol., 93: 119-128. https://doi.org/10.1016/j.fct.2016.05.005

Martin, M.D. and Woods, J.S., 2006. The safety of dental amalgam in children. Expert Opin. Drug Saf., 5: 773-781. https://doi.org/10.1517/14740338.5.6.773

Merzoug, S., Toumi, M.L., Oumeddour, A., Boukhris, N., Baudin, B., Tahraoui, A. and Bairi, A., 2009. Effect of inorganic mercury on biochemical parameters in 
Wistar rat. J. Cell Anim. Biol., 3: 222-230

Newman, S.M., 1991. Amalgam alternatives: what can compete? JADA. 122: 67-71. https://doi. org/10.14219/jada.archive.1991.0246

Osinska, E., Kanoniuk, D. and Kusiak, A., 2004. Aluminum hemotoxicity mechanisms. Annl. Univ. Mariae Curie Sklodowska. (MED), 59: 411-416.

Park, C.H., Choi, S.H., Kim, S., Lee, Y., Kim, H., Jeong, S., Rah, J.C., Seo, J., Lee, J., Chang, K., YoungJa, Y. and Suh, Y., 2000. Glutamate and aspartate impair memory retention and damage hypothalamic neurons in adult mice. Toxicol. Lett., 115: 117-125. https://doi.org/10.1016/S0378-4274(00)00188-0

Quirino, C.J., Marcília, A.F. and Renério F.J., 2012. Depression, insomnia, and memory loss in a patient with chronic intoxication by inorganic mercury. J. Neuropsychiat. Clin. Neurosci., 1: 191-205.

Ramırez-Bajo, M.J., de Atauri, P., Ortega, F., Westerhoff, H.V., Gelpı, J.L., Centelles, J.J. and Cascante, M., 2014. Effects of cadmium and mercury on the upper part of skeletal muscle glycolysis in mice. PLOS ONE, 9: 1-7. https://doi.org/10.1371/journal. pone. 0080018

Rasmussen, K.L., Skytte, L., Pilekær, C., Lauritsen, A., Jesper Lier Boldsen, J.L., Leth, P.M. and Per Orla Thomsen, P.O., 2013. The distribution of mercury and other trace elements in the bones of two human individuals from medieval Denmark: The chemical life history hypothesis. Herit. Sci., 1: 10. https://doi. org $/ 10.1186 / 2050-7445-1-10$

Rooney, J.P., 2007. The role of thiols, dithiols,nutritional factors and interacting ligands in the toxicology of mercury. Toxicology, 234: 145-156. https://doi. org/10.1016/j.tox.2007.02.016

Roya, C., Tremblaya, P. and Ayotte, P., 2017. Is mercury exposure causing diabetes, metabolic syndrome and insulin resistance? A systematic review of the literature. Environ. Res., 156: 747-760. https://doi. org/10.1016/j.envres.2017.04.038

Shaw, B.P., Dash, S. and Panigrahi, A.K., 1991. Effect of methyl mercuric chloride treatment on haematological characteristics and erythrocyte morphology of swiss mice. Environ. Pollut., 73: 4352. https://doi.org/10.1016/0269-7491(91)90095-E

Shenker, B.J., Guo, T.L. and Arnold Shapiro, I.M., 2000. Mercury-induced apoptosis in human lymphoid cells: Evidence that the apoptotic pathway is mercurial species dependent. Environ. Res., 84: 8999. https://doi.org/10.1006/enrs.2000.4078

Singer, H.S., Morris, C., Gause, C., Pollard, M., Zimmerman, A.W. and Pletnikov, M., 2009. Prenatal exposure to antibodies from mothers of children with autism produces neurobehavioral alterations: A pregnant dam mouse model. J. Neuroimmunol., 211: $\quad 39-48 . \quad$ https://doi.org/10.1016/j. jneuroim.2009.03.011

Sujatha, K., Srilatha, C., Anjaneyulu, Y. and Amaravathi, P., 2011. Lead acetate induced nephrotoxicity in Wister albino rats: A pathological immunohistochemical and ultra-structural studies. Int. J. Pharma Biosci., 2: 2-11.

Su, L.,Wang, M., Yin, S.T., Wang, H.L.,Chen, L., Sun, L.G. and Ruan, D.Y., 2008. The interaction of selenium and mercury in the accumulations and oxidative stress of rat tissues. Ecotoxicol. Environ. Safe., 70: 483-489. https://doi.org/10.1016/j. ecoenv.2007.05.018

Teixeora, F.B., Fernandes, R.M., Farias-Junior, P.M.A., Costa, N.M.M., Fernandes, L.M.P., Santana, L.N.S., Silva-Junior, A.F., Silva, M.C.F., Maia, C.S.F. and Lima, R.R., 2014. Evaluation of the effects of chronic intoxication with inorganic mercury on memory and motor control in rats. Int. J. environ. Res. Publ. Hlth., 11: 9171-9185. https://doi.org/10.3390/ ijerph110909171

Trebucobich, M.S., Hazelhoff, M.H., Chevalier, A.A., Passamonti, S., Brandoni, A. and Torres, A.M., 2014. Protein expression of kidney and liver bilitranslocase in rats exposed. Toxicol. Lett., 225: 305-310. https:// doi.org/10.1016/j.toxlet.2013.11.022

Vezer, T., Papp, A., Kurunczi, A., Parducz, A., Naray, M. and Nagymajtenyi, L., 2005. Behavioral and neurotoxic effects seen during and after subchronic exposure of rats to organic mercury. Environ. Toxicol. Pharmacol., 19: 785-796. https://doi.org/10.1016/j. etap.2004.12.045

Vieira, V.L.P., Rocha, J.B.T., Schetinger, M.R.C., Morsch, V.M., Rodrigues, S.R., Tuerlinckz, S.M., Bohrer, D. and DoNascimento, P.C., 2000. Effect of aluminum on $\delta$-aminolevulinic acid dehydratase from mouse blood. Toxicol. Lett., 117: 45-52. https:// doi.org/10.1016/S0378-4274(00)00233-2

Wadaan, M.A.M., 2009. Effect of mercury exposure on blood chemistry and liver histopathology of male rats. J. Pharmacol. Toxicol., 4: 126-131. https://doi. org/10.3923/jpt.2009.126.131

Yamane, T., 1973. The distribution In: Statistics, and introductory analysis (ed. T. Yamane). 3rd ed. Harper and Row Publishers, London. pp. 647-650.

Yoshida, M., Watanabe, C., Horie, K., Satoh, M., Sawada, M. and Shimada, A., 2005. Neurobehavioral changes in metallothionein-null mice prenatally exposed to mercury vapor. Toxicol. Lett., 155: 361-368. https:// doi.org/10.1016/j.toxlet.2004.11.001 
Yousef, M.I., 2004. Aluminum - induced changes in hematobiochemical parameters, lipid peroxidation and enzyme activity of male rabbits: Protective role of ascorbic acid. Toxicology, 199: 47-57. https://doi. org/10.1016/j.tox.2004.02.014

Zhang, H., Han, S-F., Wang, J., Wang, S-K., Sun, G-J. and Zhai, C-K., 2019. Protective effect of compound whole-grain on high fat and cholesterol diet-induced obesity and lipid accumulation in rats. Pakistan $J$. Zool., 51: 1647-1654.

Zhang, Y., Bolivar, V.J. and Lawrence, D.A., 2013. Maternal exposure to mercury chloride during pregnancy and lactation affects the immunity and social behavior of offspring. Toxicol. Sci., 133: 101111. https://doi.org/10.1093/toxsci/kft023
Zhang, Y., Gao, D., Bolivar, V.J. and Lawrence, D.A., 2011. Induction of autoimmunity to brain antigens by developmental mercury exposure. Toxicol. Sci., 119: 270-280. https://doi.org/10.1093/toxsci/kfq334

Zimmermann, L.T., dos Santos, D.B., Colle, D., dos Santos, A.A., Hort, M.A., Garcia, S.C., Bressan, L.P., Denise Bohrer, D. and Farina, M., 2014. Methionine stimulates motor impairment and cerebellar mercury deposition in methylmercury-exposed mice. $J$. Toxicol. environ. Hlth., Part A., 77: 46-56. https:// doi.org/10.1080/15287394.2014.865582

Zitzmann, M., 2006. Testosterone and the brain. Aging Male, 9: 195-199. https://doi. org/10.1080/13685530601040679 